\title{
Embryo Transfer in Fleckvieh Simmental Cows: A Preliminary Study
}

\author{
Ayşe Merve Köse ${ }^{1 *}$, Sakine Ülküm Çizmeci ${ }^{2}$ and Dursun Ali Dinç ${ }^{2}$ \\ ${ }^{1}$ Department of Obstetrics and Gynecology, Faculty of Veterinary Medicine, Hatay Mustafa Kemal University, Hatay, Turkey \\ ${ }^{2}$ Department of Obstetrics and Gynecology, Faculty of Veterinary Medicine, Selcuk University, Konya, Turkey \\ *Corresponding author: aysemervekose@mku.edu.tr; aysemervekose@gmail.com
}

Article History: $21-348 \quad$ Received: 06-Jul-2021 Revised: 13-Sep-2021 Accepted: $13-$ Sep-2021
ABS TRA C T
This study was aimed at investigating pregnancy rates achieved with multiple ovulation and embryo transfer in
Simmental cows, which are characterized by a high milk yield. For this purpose, eight cows were used as donors and
for each donor, recipient groups of 10 animals, including both heifers and cows, were established. Recipients were
synchronized by two intramuscular injections of prostaglandin F2 211 days apart. The treatment of the donors consisted
of the intravaginal placing of a CIDR on day 0, the application of $400 \mathrm{mg}$ FSH in decreasing doses, starting on day four,
the administration of prostaglandin F2 $\alpha$ and the removal of CIDR on day 8 . The donors were inseminated twice on day
9 and once on day 10 . Uterine flushing was performed, trans-cervically, on day 7 after insemination. The ovulation rate
was determined as $12.25 \pm 1.42$. Sixteen transferable embryos $(2.0 \pm 3.23,88.9 \%)$ were collected. The 12 embryos of
Grade 1 quality and the 4 embryos of Grade 2 quality were transferred by transcervical route to 12 heifers and 4 cows,
respectively. The pregnancy rates achieved in the heifers and cows were $50 \%$ and $25 \%$, respectively (P>0.05). As a
result, the MOET scheme applied in Fleckvieh Simmental Cows produced satisfactory superovulatory responses and
resulted in the collection of quality embryos. The embryo recovery rate was poor but, overall, the ovulation rate, the
quality of the collected embryos and the pregnancy rates achieved under field conditions in this preliminary study were
considered to be satisfactory.

Key words: Embryo transfer, Fleckvieh Simmental cow, Superovulation, Synchronization

\section{INTRODUCTION}

Cattle have a longer generation interval and a relatively lower fertility rate when compared to other animal species. Multiple ovulation and embryo transfer (MOET) schemes increase genetic improvement and reduce the generation interval (Loi et al. 1998; Velazquez 2008). Thus, embryo transfer aids as a favourable technique in achieving genetic advance and an increased number of valuable breeders within a short period of time (Velazquez 2008; Fufa et al. 2016).

Bovine embryo transfer technology involves the selection and management of donor and recipient animals, and the collection and transfer of embryos. The main objective targeted with the use of embryo transfer in cattle is to increase the reproductive rate of valuable females (Fufa et al. 2016; Kidie 2019). Thereby, the number of progenies of valuable female increases to a level at least five times higher than that normally achieved (Sağırkaya 2009). Embryo transfer is described as the transfer of embryos, either harvested in vivo from the genital tract of a donor animal or produced in vitro under laboratory conditions, to one or more synchronized recipients (Hasler 2004; Sağırkaya 2009; Hansen 2020). The stages of in vivo embryo production include the selection of donor and recipient animals, the synchronization of the selected donors and recipients' oestrous cycles, the induction of superovulation and subsequent insemination of the donors, the collection (via uterine flushing), evaluation and transfer of embryos (Kaymaz 2012; Phillips and Jahnke 2016).

Donors, fewer than five calving, are selected among normal cyclic animals free from hereditary diseases, reproductive disorders and diseases that may adversely affect fertility and have a high genetic potential and high production yields (Mapletoft and Bo 2006; Kidie 2019; Mebratu et al. 2020). Donors should be animals of superior genetic merit that are capable of producing a high number of useable embryos (Genzebu 2015; Kidie 2019). On the other hand, recipients should be healthy, normal cyclic animals with no congenital disorder, disease that may adversely affect fertility, or reproductive, nutritive and metabolic problem, which have a normal body condition score (Sağırkaya 2009; Phillips and Jahnke 2016; Mebratu et al. 2020).

Cite This Article as: Köse AM, Çizmeci SÜ and Dinç DA, 2022. Embryo transfer in Fleckvieh Simmental cows: A preliminary study. International Journal of Veterinary Science 11(2): 196-200. https://doi.org/10.47278/ journal.ijvs/2021.095 
Superovulation refers to the induction of ovulation of more follicles than normally observed during one oestrus cycle. The aim of applying superovulation treatment to cows is to collect a maximum number of transferable embryos with a highly implantation potential (Mapletoft and Bo 2006). For this purpose, gonadotropins such as follicle stimulating hormone (FSH) and equine chorionic gonadotropin (eCG), formerly called pregnant mare serum gonadotropin-PMSG) are used and their impact is enhanced through their combined administration with gonadotropinreleasing hormone $(\mathrm{GnRH})$ and progesterone (Machaty et al. 2012; Phillips and Jahnke 2016). For best results, cows treated for superovulation are inseminated in mid- or late oestrus and generally, two inseminations suffice in harvesting high quality embryos (Machaty et al. 2012).

Uterine flushing is performed on the $7^{\text {th }}$ day by recovering the flushing medium channelled into the uterine horns through catheters placed in the uterine horn via the vagina and cervix. Embryos collected by uterine flushing are first evaluated for their quality before being transferred (Bo and Mapletoft 2013; Genzebu 2015; Fufa et al. 2016). Two major factors that affect the success of MOET schemes are the variability in embryo production of donors and low pregnancy rates (Velazquez 2008).

The aim of this study was to compare the responses of superovulation of high milk yield Fleckvieh Simmental cows, the quality of the embryo obtained and the pregnancy rates after embryo transfer.

\section{MATERIALS AND METHODS}

All the experimental procedures followed in this study were approved by the Local Ethics Board for Animal Experiments of Selcuk University (SÜVDAMEK).

\section{Location, Selection of Donors and Recipients}

This study was carried out in a Simmental Dairy Cattle Farm (Eren Gıda San ve Tic. Ltd. Şti. Çorum/Turkey). Eight Simmental cows were used as donors and for each donor, recipient groups of 10 Simmental heifers and cows were established. In the selection of donors, milk yield records, reproductive history and resistance to diseases were taken into consideration. The donors, approximately 4 ages, were selected among regular cyclic animals that were at least 50-60 days postpartum, had a body condition score of 3-4 as described by Andersen et al. (1991). The recipients, Simmental cows in 1.5 to 3 ages, were selected among the animals, having adequate body size, reproductively healthy and exhibiting calving ease.

\section{Superovulation Protocol}

Superovulation protocol was applied to the eight Simmental cows [May (n:2), June (n:2) and July (n:4)] included to this study. The protocol was designed according to Lamb et al. (2016). Thus, in the evening of day 0 , a controlled internal drug-release dispenser containing $1.38 \mathrm{~g}$ of progesterone (CIDR $1380^{\circledR}$, Pfizer) was inserted in the vagina of the donors. In the evening of the second day, GnRH $\left(100 \mu \mathrm{g}\right.$, im) $\left(\right.$ Gestavet $^{\circledR} \mathrm{GnRH}$, HIPRA) was administered to the donors. For superovulation, $400 \mathrm{mg}$ of FSH (Folltropin-V, Bioniche Animal Health Inc., Ontario, CANADA), in decreasing doses $(3: 3,3: 2.5,2.5: 2,2: 2 \mathrm{~mL})$ at $12 \mathrm{~h}$-intervals, was administered to each donor, starting in the evening of day 4. Besides, the donors were treated with $35 \mathrm{mg}$ PGF $2 \alpha$ on the evening of the $7^{\text {th }}$ day and with $25 \mathrm{mg}$ on morning of the 8th day; CIDRs were withdrawn on day 8. Artificial insemination of the donors was performed using double semen doses, in the morning-evening on 9th day and in the morning on $10^{\text {th }}$ day; GnRH $(100 \mu \mathrm{g})$ was applied intramuscularly at the time of the first artificial insemination. Luteinizing hormone-LH (1500IU) was applied to the donors on the morning of day 13 .

\section{Synchronization Protocol of Recipients}

The heifers and cows that selected as recipients were synchronized by the administration of two injections of $25 \mathrm{mg}$ PGF2 $\alpha$ (Dinolytic ${ }^{\circledR}$ Pfizer) at 11 days apart. Reproductive tract scoring by rectal palpation was performed on the potential recipients. Animals having a corpus luteum (CL) with a minimum diameter of $1.5 \mathrm{~cm}$ on their ovaries and having 4 or 5 genital score (Andersen et al. 1991) were selected as recipients.

\section{Collection and Transfer of Embryos}

Superovulation responses and ovulation rates were evaluated with the number of CLs determined by rectal palpation and ultrasonography in the ovaries on the 7th day after the first insemination. The uteri were irrigated by one litre of lactated Ringer's solution $\left(1000 \mathrm{~mL}\right.$, IV, Polifleks ${ }^{\circledR}$, Polifarma, Istanbul) containing $1 \%$ of foetal calf serum (500ml; C8056, FCS, Sigma, USA) by 2-way silicone catheter (Luer Lock CH 18, Minitube, Germany). The catheter was positioned in the uterine horns and embryos were collected by routine flushing method. Harvested embryos were scored according to developmental stage and quality following the recommendations of the International Embryo Transfer Society under invert microscope (Olympus IX71). Grades 1 and 2 were defined as transferable embryos and were loaded into sterile $0.25 \mathrm{~mL}$ embryo straws. The selected embryos were transferred to the recipients within $4 \mathrm{~h}$ after collection. The pregnancy examination was performed on day 21 via ultrasonography (Falko, Pie Medical, the Netherlands) by using a transrectal probe $(5-7.5 \mathrm{MHz})$.

\section{Statistical Analysis}

Pregnancy rates were assessed using the $\chi 2$ test, of the SPSS 22.0 software package.

\section{RESULTS}

Total 98 corpora lutea and 6 follicles with a diameter ranging to $1.50-2.94 \mathrm{~cm}$ were detected in the ovaries of the animals. Eighteen embryos ( 2 of which were Grade 1 compact morulae, 9 of which were Grade 1 morulae, 1 of which was a Grade 1 early-stage blastocyst, 2 of which were Grade 2 compact morulae, 2 of which were Grade 2 morulae, one was degenerate, and one was composed of four cells) were harvested from flushing fluids.

The mean number of corpora lutea recorded (ovulation rate) was $12.25 \pm 1.42$. The mean number of embryos obtained was $2.25 \pm 3.15$ and the embryo recovery rate was $18.36 \%$. According to developmental stage and quality of harvested embryos, the mean number of transferable embryos was determined as 2.0 23.23 . Besides, the distribution of embryo quality was given in Table 1 . 
Table 1: Transferable embryos collected $(n=18)$ from donor animals $(n=8)$ and distribution of embryo quality

\begin{tabular}{lll}
\hline Embryo category & Number out of 18 & $\%$ \\
\hline Transferable embryo & 16 & 88.9 \\
Grade 1 (Excellent) embryo & 12 & 66.7 \\
Grade 2 (Fair) embryo & 4 & 22.2 \\
Grade 4 (Degenerate) embryo & 2 & 11.1 \\
\hline
\end{tabular}

The harvested embryos were transferred to 12 recipient heifers and 4 recipient cows, having a genital score of either 4 or 5. Pregnancy examinations performed on day 21 post-transfer revealed a pregnancy rate of $50 \%$ in the recipient heifers and $25 \%$ in the recipient cows $(\mathrm{P}>0.05)$ (Table 2).

Table 2: Number of embryo transfers to recipient animals and pregnancy rate

\begin{tabular}{|c|c|c|c|c|}
\hline Recipient animals & Heifer & Cow & Total & Statistics \\
\hline $\begin{array}{l}\text { Number of single embryo } \\
\text { transfers }\end{array}$ & 12 & 4 & 16 & $\begin{array}{l}\chi^{2} \text { Value }= \\
0.762\end{array}$ \\
\hline Number of pregnant animals & 6 & 1 & 7 & $\mathrm{df}=1$ \\
\hline Pregnancy rate $\%$ & 50 & 25 & 43.75 & $\mathrm{P}=0.585$ \\
\hline
\end{tabular}

\section{DISCUSSION}

The main factor, which limits the extensive use of embryo transfer in cattle, is the unpredictability and variability of the superovulatory response (Kafi and McGowan 1997; Vieira et al. 2014). Several factors, including among others, age, breed, season, nutrition, individual response, type of gonadotropin used, subclinical infection and lactation, affect the response of cows to superovulation (Kafi and McGowan 1997; Akyol et al. 2014; Mikkola et al. 2019). In their study, in which they compared different progesterone treatment regimens in Holstein Friesian cows and applied a 4 day-superovulation scheme based on the administration of decreasing FSH doses given twice a day, Akyol et al. (2014) determined the mean CL number as $4.82 \pm 0.29$ in the group that was applied progesterone-releasing intravaginal devices (PRID) and as 6.71 \pm 0.29 in the group that was applied ear implants. In Brown Swiss cows, which were synchronized with progesterone and estradiol valerate, Bülbül et al. (2010) determined the mean number of CL postsuperovulation as $8.4 \pm 1.4$ in the control group, and as $9.2 \pm 1.6$ in the treatment group. Upon investigating superovulatory responses in different cattle breeds, Karaşahin et al. (2016) determined that following the placement of CIDR devices and the administration of decreasing FSH doses for 4 days in all groups, the mean numbers of CL in Holstein, Brown Swiss and Simmental cows were $8.36 \pm 2.37,10.22 \pm 2.62$ and $15.92 \pm 2.27$, respectively. In the present study, the superovulation of Simmental cows, characterized by high meat yield, resulted in a mean of $12.25 \pm 1.42 \mathrm{CL}$ which is higher than the responses of the different breeds mentioned above.

In the present study, the embryo recovery rate $18.36 \%$. While no embryo was able to be harvested from 4 of the donors by uterine flushing, a number varying from 1 to 10 was harvested from the other 4 donors. In this study, it was found that the response to superovulation was good, but embryo recovery rate was low. In previous research, Siedel and Siedel (1991) reported that no embryos could be obtained in $20-30 \%$ of donors after superovulation and three to fifty different qualities embryos could be recovered from other 70-80 perceant of donors. Kanagawa et al. (1995) indicated that the mean number of corpora lutea after superovulation in 26 reproductively healthy cows was 11.3 , embryo recovery rate after flushing was $9.5 \%$ and fertilization rate was $6.8 \%$. Betterridge (1997) reported that the unusual endocrine conditions after superovulation adversely affect embryo recovery and viability, and embryo recovery rates would decrease over time after ovulation. The embryo recovery rates achieved in the present study were lower than those reported in some other studies (Bülbül et al. 2010; Akyol et al. 2014; Hussein et al. 2014; Karaşahin et al. 2016). Kanagawa et al. (1995) reported that the differences in embryo recovery rates between studies were related to factors such as washing time, washing media and washing number, catheter type and positioning of the catheter, technician experiences, etc. The low embryo recovery rate obtained in the present study may be caused by these factors. Ultimately, both the rates of embryo recovery and pregnancy rates of recipients vary widely even between experienced operators working in similar conditions (Hasler 2010).

In the present study, three out of the four donors, from which no embryo was harvested after superovulation treatment, were observed to have undergone the MOET scheme in July. And the remaining one donor yielded two degenerate embryos. These results are in support of the opinion that the number of degenerate embryos and the rate of embryonic death increase with superovulation treatment performed under heat stress. Heat stress is a factor that adversely affects the fertility of dairy cows inseminated in summer. The increase of the temperature of the ovaries in cows under heat stress shows negative impact on oocyte quality. Heat stress also alters the intrauterine environment as the blood flow decreases and the temperature of the uterus increases. These alterations inhibit embryonic development, increase the rate of early embryonic death. High environmental temperature particularly affects embryos in the pre-implantation phase (Ergene 2009; Samal 2013). Heat stress also affects endometrial prostaglandin secretion and causes embryonic death due to premature luteolysis (De Rensis and Scaramuzzi 2003; Hansen 2008; Ergene 2009; Samal 2013). An increase greater than $0.5^{\circ} \mathrm{C}$ in the temperature of the uterus has been reported to decrease the conception rate $(12.8 \%)$ (Hansen 2008). Based on their assessment of the results of superovulation treatment performed during the hot and cold months of the year in heifers and cows in the period between 2007-2010, Vieira et al. (2014) reported that the CL number, embryo recovery rate and degenerate embryo rate of the heifers were $8.1 \pm 0.5,64.1 \%$ and $9.6 \%$, respectively, in the cold season, and $6.8 \pm 0.4,53.1 \%$ and $11.9 \%$, respectively, in the hot season. These researchers also reported the CL number, embryo recovery rate and degenerate embryo rate of the cows as $11.3 \pm 0.7,79.3 \%$ and $8.6 \%$, respectively, in the cold season and as $9.8 \pm 0.7,76.45$ and $11.1 \%$, respectively, in the hot season.

Another major factor limiting the success of embryo transfer programmes applied after superovulation treatment is the number and quality of the embryos yielded. Only embryos of quality grade 1 and 2, developed to the stage of compact morula or beyond, are considered as transferable (Youngs 2007; Genzebu 2015). The American Embryo Transfer Association reported that the mean number of high-quality embryos obtained post- 
superovulation was 6.6 in beef cattle and 5.7 in dairy cattle (Hasler 2010). Also, Galli et al. (2003) obtained an average of 4-6 transferable embryos after superovulation in a MOET programme in cows. After superovulation using PMSG, Akyol et al. (2004) collected 75 embryos and 30 of them were transferable embryos; $20(26.6 \%)$ were graded as excellent, $10(13.3 \%)$ as fair and $4(5.3 \%)$ poor. Furthermore, after superovulation using FSH, Köse et al. (2007) reported the numbers of Grade 1 and Grade 2 embryos as $1.9 \pm 0.7$ and $1.9 \pm 0.7$, respectively, and indicated the number of transferable embryos as 4.1 1.0 . After applying superovulation treatment with CIDR+FSH, Hussein et al. (2014) reported the mean number of transferable embryos as $4.86 \pm 0.57(68.46 \%)$, and the mean numbers of Grade 1, Grade 2 and degenerate embryos as $3.68 \pm 0.50(50.54 \%), 0.90 \pm 0.30(14.31 \%)$ and $2.33 \pm 0.40$ $(31.36 \%)$, respectively. In the present study, the percentages of Grade 1, Grade 2, degenerate and transferable embryos were $66.7,22.2,11.1$ and $88.9 \%$, respectively (Table 1 ). When compared to the literature referred to above, the number of good quality-transferable embryos obtained in the present study was higher. This favourable difference may have arisen from different factors such as management conditions, nutrition, age, breed, and type of gonadotropin used (Silva et al. 2009). On the other hand, the mean number of transferrable embryos per donor obtained in this study was low; this should be attributed mainly to the low collection rate $(18.36 \%)$. So, besides the rather high superovulation rate $(12.25 \pm 1.42 \mathrm{CL})$ and the high ratio of Grade 1 and 2 embryos, we ended up with low mean number of transferrable embryos $(2.0 \pm 3.23)$ per donor.

The criterion for the success of bovine embryo transfer is usually the pregnancy rate (Gordon 1996). Generally, the pregnancy rates after non-surgical embryo transfers in cows are $50-70 \%$ and about $10 \%$ lower if frozen thawed embryos are used (Gordon 2004). Pérez-Mora et al. (2020) stated that they achieved a pregnancy rate of $75 \%$ with embryos produced in vivo and $54.14 \%$ with embryos produced in vitro after embryo transfer. Rodrigues et al. (2018) showed that pregnancy rates were determined as $53 \%$ for fresh embryos and $44 \%$ for frozen embryos. Lestari et al. (2019) in their study using limousine embryos, they reported a pregnancy rate of $35 \%$ ( 7 out of 20 cows) in Indonesian cattle after embryo transfer. Barsuren et al. (2019) reported that pregnancy rate was $52.8 \%$. In the present study, an overall pregnancy rate of $43.75 \%$ was achieved $(50 \%$ and $25 \%$, in heifers and cows, respectively. Jeon et al. (2013) reported recipient pregnancy rates of $42.55 \%$ and $48.28 \%$ after embryo transfers performed after oestrus induced by CIDR+PG and natural oestrus, respectively. Faizah et al. (2018) showed that out of eight recipients, five cows were detected pregnant, a $62.5 \%$ pregnancy rate. Higher pregnancy rates have been reported by Spell et al. (2001) after the single transfer of 122 fresh embryos to 101 animals $(82.8 \%)$ and 326 frozen-thawed to 225 animals $(69 \%)$, and by Hasler (2001) after the single transfer of 9023 fresh embryos $(68.3 \%)$ and 2650 fresh embryos $(77.1 \%)$, at different locations and time periods.

Lamb (2005) reported that the best indicator to be taken into consideration when assessing the suitability of a potential recipient for embryo transfer, after transrectal ultrasonography and the evaluation of the ovaries, was the detection of oestrus followed by the palpation of a corpus luteum, regardless of its size and quality. Although Spell et al. (2001) have suggested that recipients could be selected regardless of oestrus detection and the size and quality of the corpus luteum palpated, Hasler (2004) pointed out to embryo quality and recipient suitability as the main two factors influential on pregnancy rates. In agreement with the latter, in the present study, satisfactory pregnancy rates were achieved (overall $43.75 \% ; 50 \%$ and $25 \%$, in heifers and cows, respectively) following oestrous synchronization and selection of recipients based on reproductive tract scoring by rectal palpation.

\section{Conclusion}

Although the superovulatory response of high yield Simmental cows were satisfactory, the embryo recovery rate was very low, resulting in the collection of very low number of transferrable embryos. Nevertheless, the quality of the embryos obtained, and the post-transfer pregnancy rates are considered to be satisfactory for a first attempt under field conditions.

\section{Author's Contribution}

Ayşe Merve KÖSE: Investigation, Clinical Applications, Laboratory studies, Writing - Original Draft, Writing - Review \& Editing Sakine Ülküm ÇİZMECİ: Clinical Applications, Laboratory studies, Writing Review \& Editing Dursun Ali DİNÇ: Conceptualization, Methodology, Resources, Clinical Applications, Writing Review \& Editing

\section{REFERENCES}

Akyol N, Kizil SH, Satılmış M, Karaşahin T and Erat S, 2014. The results of consecutive superovulations in cows by induction with various exogenous progesterone routes. Turkish Journal of Veterinary Animal Sciences 38: 157-160. https://doi.org/10.3906/vet-1304-43

Akyol N, Kizıl SH and Tuncer PB, 2004. İneklerde süperovulasyon ve embryo transferi çalışmaları. Lalahan Hayvancılık Araştırma Enstitüsü Dergisi 44: 1-5.

Andersen KJ, LeFever DG, Brinks JS and Odde KG, 1991. The use of reproductive tract scoring in beef heifers. Agri Practice 12: 106-111.

Barsuren E, Kim SH, Lee HJ and Yoon JT, 2019. Effect of embryo transfer seven days after artificial insemination with sexed and conventional semen from superovulated cattle. Journal of Animal Reproduction and Biotechnology 34: 106110. https://doi.org/10.12750/JARB.34.2.106

Betterridge KJ, 1997. Techniques and results in cattle superovulation. In: Betterridge KJ (ed), Embryo Transfer in Farm Animals. Monograph, Ottawa, Canada Department of Agriculture, pp: 1-9.

Bo GA and Mapletoft RJ, 2013. Evaluation and classification of bovine embryos. Animal Reproduction 10: 344-348.

Bülbül B, Kırbaş M, Köse M and Dursun Ş, 2010. Investigation of superovulation response in Brown Swiss cows after synchronization using progesterone and oestradiol valerate. Kafkas Universitesi Veteriner Fakultesi Dergisi 16: 463-468. https://doi.org/10.9775/kvfd.2009.1024

De Rensis F and Scaramuzzi RJ, 2003. Heat stress and seasonal effects on reproduction in the dairy cow-a review. Theriogenology 60: 1139-1151. https://doi.org/10.1016/ S0093-691X(03)00126-2

Ergene O, 2009. İneklerde kromozomal, hormonal, beslenme sorunlarına ve 1sı stresine bağlı erken embriyonik ölümler. Dicle Üniversitesi Veteriner Fakültesi Dergisi 2: 36-41.

Faizah HMS, Richard F, Meena P, Stanley KL, Amriana H, Alhassany A, Yadav SB, Mariel L, Crouch B, Son and Saipul 
BAR, 2018. Multiple ovulation embryo transfer (MOET) in dairy cattle in Gatton. Malaysian Journal of Veterinary Research 9: 109-116.

Fufa N, Abera D and Kabeta T, 2016. Review on bovine embryo transfer. European Journal of Biological Sciences 8: 79-84. https://doi.org/10.5829/idosi.ejbs.2016.79.84

Galli C, Duchi R, Crotti G, Turini P and Ponderato N, 2003. Bovine embryo technologies. Theriogenology 59: 599-616. https://doi.org/10.1016/S0093-691X(02)01243-8

Genzebu D, 2015. A review of embryo transfer technology in cattle. Global Journal of Animal Scientific Research 3: 562561.

Gordon I, 1996. Controlled Reproduction in Cattle and Buffaloes. CAB International, Wallingford, UK, pp: 245-255.

Gordon IR, 2004. Reproductive Technologies in Farm Animal. CABI Publishing, pp: 82-107.

Hansen PJ, 2008. Getting cows pregnant when it's hot-a growing problem with some novel solutions. Partners in Reproduction 4: 1-9.

Hansen PJ, 2020. The incompletely fulfilled promise of embryo transfer in cattle-why aren't pregnancy rates greater and what can we do about it. Journal of Animal Science 98: 120. https://doi.org/doi:10.1093/jas/skaa288

Hasler JF, 2010. Bovine embryo transfer: are efficiencies improving? In: Proceedings Applied Reproductive Strategies Conference, Nashville, TN, pp: 265-282.

Hasler JF, 2001. Factors affecting frozen and fresh embryo transfer pregnancy rates in cattle. Theriogenology 56: 14011415. https://doi.org/10.1016/S0093-691X(01)00643-4

Hasler JF, 2004. Factors influencing the success of embryo transfer in cattle. In: Proceedings of the $23^{\text {rd }}$ World Buiatrics Congress, Quebec City, Canada, pp: 1-5.

Hussein MM, Aziz RA, Abdel-Wahab A and El-Said H, 2014. Preliminary study of factors affecting the superovulatory response of high producing dairy cows superstimulated regardless of the stage of estrous cycle in Egypt. Beni-Suef University Journal of Basic and Applied Sciences 3: 286292. https://doi.org/10.1016/j.bjbas.2014.11.002

Jeon SH, Jung KS, Choi JW, Heo YT and Xu YN, 2013. Optimization of in vivo embryo production and pregnancy following embryo transfer in Hanwoo cattle. Journal of Embryo Transfer 28: 307-314. https://doi.org/10.12750/ JET.2013.28.4.307

Kafi M and McGowan MR, 1997. Factors associated with variation in the superovulatory response of cattle. Animal Reproduction Science 48: 137-157. https://doi.org/ 10.1016/S0378-4320(97)00033-X

Kanagawa H, Shimohira I and Saitoh N, 1995. Manual of Bovine Embryo Transfer. Livestock Technology Association 1-44.

Karaşahin T, Kızıl SH, Satılmış M, Akyol N and Dursun Ş, 2016. Süperovulasyon uygulamasına farklı irkların verdikleri cevapların araştırılması. Journal of Advances in VetBio Science and Techniques 1: 1-5.

Kaymaz M, 2012. Yardımc1 üreme teknikleri. In: Semacan A, Kaymaz M, Fındık M, Rişvanlı A and Koker A (ed). Çiftlik Hayvanlarında Doğum ve İnfertilite. 1st Ed, Medipres, Malatya, Turkey, pp: 695-811.

Kidie HA, 2019. Review on growth and development of multiple ovulation and embryo transfer technology in cattle. World Scientific News, 127: 191-211.

Köse M, Dursun Ş, Bülbül B and Kırbaş M, 2007. İsviçre esmeri ineklerde FSH ve PMSG'ye verilen süperovulasyon cevabının karşıllaştırılması. Hayvancılık Araştırma Dergisi 17: $1-5$.

Lamb GC, Mercadante VRG and Fontes PLP, 2016. Donor and recipient management to optimize embryo technology success. In: Proceedings of Applied Reproductive Strategies in Beef Cattle. Des Moines, Iowa, USA, pp: 197-209.

Lamb GC, 2005. Factors affecting an embryo transfer program. In: Proceedings of Applied Reproductive Strategies in Beef Cattle. Lexington, Kentucky, pp: 257-266.
Lestari TD, Ismudiono I, Sardjito T, Yamato O, Takagi M, Yabuki A and Srianto P, 2019. Breeding performance of Indonesian beef cattle as recipients for embryo transfer. Journal of Veterinary Medical Science 81: 1688-1691. https://doi.org/10.1292/jvms.19-0429.

Loi P, Ptak G, Dattena M, Ledda S and Naitana S, 1998. Embryo transfer and related technologies in sheep reproduction. Reproduction Nutrition Development 38: 615-628.

Machaty Z, Peippo J and Peter A, 2012. Production and manipulation of bovine embryos: techniques and terminology. Theriogenology 7: 937-950. https://doi.org/ 10.1016/j.theriogenology.2012.04.003

Mapletoft RJ and Bo GA, 2006. Bovine embryo transfer. In: Medicine, I.V.I.S (Ed): IVIS Reviews in Veterinary International Veterinary Information Service, Ithaca, NY (www. ivis.org), R0104.0616.

Mebratu B, Fesseha H and Goa E, 2020. Embryo transfer in cattle production and its principle and applications. International Journal of Pharmacy \& Biomedical Research 7: 40-54. http://doi.org/10.18782/2394-3726.1083

Mikkola M, Hasler JF and Taponen J, 2019. Factors affecting embryo production in superovulated Bos taurus cattle Reproduction, Fertility and Development 32: 104-124. http://doi.org/10.1071/RD19279

Pérez-Mora A, Segura-Correa JC, Peralta-Torres JA, 2020. Factors associated with pregnancy rate in fixed-time embryo transfer in cattle under humid-tropical conditions of México. Animal Reproduction 17: e20200007. https://doi.org/ 10.1590/ 1984-3143-AR2020-0007

Phillips PE and Jahnke MM, 2016. Embryo transfer (techniques, donors, and recipients). Veterinary Clinics Food Animal Practice 32: 365-385. https://doi.org/10.1016/j.cvfa. $\underline{2016.01 .008}$

Rodrigues MCC, Bonotto ALM, Acosta DAV, Boligon AA, Corrêa MN and Brauner CC, 2018. Effect of oestrous synchrony between embryo donors and recipients, embryo quality and state on the pregnancy rate in beef cattle. Reproduction in Domestic Animals 53: 152-156. https://doi.org/10.1111/rda.13084

Sağırkaya H, 2009. Sığırlarda embriyo transfer uygulaması ve Türkiye açısından önemi. Uludă̆ Üniversitesi Veteriner Fakültesi Dergisi 28: 11-20.

Samal L, 2013. Heat stress in dairy cows-reproductive problems and control measures. International Journal of Livestock Research 3: 14-23.

Siedel GE and Siedel SM, 1991. Training manual for embryo transfer in cattle, FAO Animal Production and Health Paper 77, Rome.

Silva JCC, Alvarez RH, Zanenga CA and Pereira GT, 2009. Factors affecting embryo production in superovulated Nelore cattle. Animal Reproduction 6: 440-445.

Spell AR, Beal WE, Corah LR and Lamb GC, 2001. Evaluating recipient and embryo factors that affect pregnancy rates of embryo transfer in beef cattle. Theriogenology 56: 287-297. https://doi.org/10.1016/S0093-691X(01)00563-5

Velazquez MA, 2008. Assisted reproductive technologies in cattle: applications in livestock production, biomedical research and conservation biology. The Annual Review of Biomedical Sciences 10: 36-62. https://doi.org/10.5016/ 1806-8774.2008.v10p36

Vieira LM, Rodrigues CA, Mendanha MF, Sá Filho MF and Sales JNS, 2014. Donor category and seasonal climate associated with embryo production and survival in multiple ovulation and embryo transfer programs in Holstein cattle. Theriogenology 82: 204-212. https://doi.org/10.1016/ j.theriogenology.2014.03.018

Youngs CR, 2007. Embryo Transfer in Beef Cattle. In: Proceedings of Applied Reproductive Strategies in Beef Cattle, Billings, Montana, pp: 267-284. 